\title{
Pemberian Posisi untuk Mengatasi Masalah Pengosongan Lambung pada Bayi Prematur
}

\author{
Natalia Devi Oktarina1, Yeni Rustina², Defi Efendi ${ }^{2,3 *}$ \\ ${ }^{1}$ Fakultas Keperawatan Universitas Ngudi Waluyo, Semarang, Jawa Tengah, Indonesia \\ ${ }^{2}$ Departemen Keperawatan Anak, Fakultas Ilmu Keperawatan, Universitas Indonesia, Depok, \\ Indonesia \\ ${ }^{3}$ Neonatal Intensive Care Unit (NICU), Rumah Sakit Universitas Indonesia, Depok, Indonesia \\ *defiefendi@ui.ac.id
}

\begin{abstract}
Gastric emptying in premature infants is slower than aterm infant aterm for 12 hours and some cases reach 22-36 hours. This slow emptying of the stomach causes to increase the volume of gastric residual and raising the risk for infants to experience gastroesophageal reflux, vomiting, aspiration and necrotizing etherocolitis. This study aims to analyze the effectiveness of positioning on gastric emptying show from gastric residual in premature infants in the Perinatology RSUPN Cipto Mangunkusumo. The research design used in this research is quasi experiment on 20 premature infants with consecutive sampling technique. The data analysis used Wilcoxon test for gastric residual. The study showed a difference in average abdominal distensionand gastric residual in right lateral position, left lateral positions and pronation is significant so that it can be concluded effective positioning to accelerate gastric emptying. Based on these results then the positioning can be recommended to be an alternative nursing care in overcoming the problem of gastric emptying in premature infants.
\end{abstract}

Keywords: premature infants, positioning, gastric emptying

\begin{abstract}
Abstrak
Pengosongan lambung pada bayi prematur lebih lambat dibandingkan bayi aterm yaitu selama 12 jam dan beberapa kasus mencapai 22- 36 jam. Pengosongan lambung yang lambat ini menyebabkan volume residu lambung mengalami peningkatan sehingga menimbulkan risiko pada bayi untuk mengalami refluks gastroesofageal, muntah, aspirasi dan necrotizing eterocolitis.Penelitian ini bertujuan untuk menganalisis efektivitas pemberian posisi terhadap pengosongan lambung dilihat dari pengeluaran residu lambung pada bayi prematur di Ruang Perinatologi RSUPN Cipto Mangunkusumo. Desain penelian yang digunakan dalam penelitian ini yaitu quasi experiment pada 20 bayi prematur dengan teknik consecutive sampling. Analisis data menggunakan uji Wilcoxon untuk pengukuran residu lambung pada berbagai posisi yang diberikan. Penelitian menunjukkan adanya perbedaan rata-rata pengeluaran residu lambung dan muntah pada posisi miring kanan, miring kiri dan pronasi yang bermakna sehingga dapat disimpulkan pemberian posisi miring kanan dan miring kiri lebih efektif untuk mempercepat pengosongan lambung. Berdasarkan hasil ini maka pemberian posisi dapat direkomendasikan menjadi salah satu alternatif asuhan keperawatan dalam mengatasi masalah pengosongan lambung pada bayi prematur.
\end{abstract}

Kata kunci: bayi prematur, pemberian posisi, pengosongan lambung

Jurnal Keperawatan Raflesia, Volume 2 Nomor 2, November 2020

ISSN: (p) 2656-6222, (e) 2657-1595 DOI 10.33088/jkr.v2i2.505

Available online: https://jurnal.poltekkes-kemenkes-bengkulu.ac.id/index.php/jkr 


\section{PENDAHULUAN}

Bayi baru lahir akan beradaptasi dengan lingkungan ekstrauterin. Bayi prematur harus melakukan adaptasi dengan lingkungan ekstrauterin seperti juga bayi yang lahir cukup bulan, tetapi fungsi fisiologis pada bayi prematur mengalami imaturitas sesuai dengan usia kehamilannya (Potts \& Mandleco, 2012). Bayi yang lahir prematur memiliki risiko tinggi untuk mengalami komplikasi yang dapat berdampak terhadap pertumbuhan dan perkembangan bayi dan keluarga dimasa mendatang, bahkan dapat menyebabkan kematian (Hockenberry, Wilson, Winkelstein \& Schwartz, 2013).

Sistem gastrointestinal pada bayi prematur juga mengalami proses adaptasi. Proses adaptasi dari lingkungan intrauterin ke ekstrauterin pada awal periode kelahiran akan menyebabkan bayi prematur mengalami kehilangan berat badan 15-20\%. Penurunan berat badan ini disebabkan karena peningkatan kebutuhan energi dari proses respirasi, termoregulasi, sintesis jaringan dan metabolisme tubuh (Carter, 2012). Pemenuhan kebutuhan nutrisi pada bayi prematur membutuhkan perhatian yang optimal seiring dengan usaha untuk memenuhi dukungan kebutuhan sistem organ yang lain, karena kebutuhan nutrisi bayi prematur diperlukan sebagai energi untuk mempercepat pertumbuhan.

Imaturitas sistem gastrointestinal dapat menjadi hambatan yang paling sering dialami oleh bayi prematur dalam pemenuhan kebutuhan nutrisi enteral. Hambatan yang sering terjadi yaitu adanya intoleransi dalam pemberian minum.
Kejadian intoleransi pemberian minum pada bayi prematur sekitar 16-29\% dan terjadi akibat imaturitas sistem gastrointestinal (Fanaro, 2013). Mekanisme sistem gastrointestinal pada bayi prematur yang mengalami imaturitas adalah pengosongan lambung. Pengosongan lambung yang lebih lambat dalam 12 jam dan beberapa kasus mencapai 22- 36 jam menyebabkan volume residu lambung mengalami peningkatan sehingga menimbulkan risiko pada bayi untuk mengalami gastroesofageal refluks, muntah, aspirasi dan necrotizing eterocolitis (Abdelmaaboud, Eissa, Eldakrouri, \& Mohammed, 2015).

Intervensi keperawatan yang dapat dilakukan untuk menurunkan residu lambung agar mempercepat pengosongan lambung dan mentoleransi pemberian minum yaitu pengaturan posisi, sehingga bayi dapat menerima nutrisi enteral secara penuh. Penelitian yang dilakukan oleh Sangers, et.al.(2013) tentang pemberian posisi terhadap pengeluaran residu lambung pada bayi prematur menunjukkan pengeluaran residu lambung lebih sedikit pada posisi miring kanan dan pronasi dibandingkan dengan miring kiri dan supinasi. Hal ini sesuai dengan penelitian Hwang, Ju, Kim, Lee, dan Kim (2003) menyatakan bahwa posisi miring kanan dan posisi pronasi setelah menyusui dapat menurunkan residu lambung dibandingkan dengan posisi miring kiri.

Dari hasil studi pendahuluan yang dilakukan selama 3 minggu di ruangan didapatkan data bahwa dari 15 bayi 
prematur yang dirawat dan memperoleh minum enteral, 6 bayi mengalami distensi abdomen setelah pemberian minum dan terdapat muntah kecoklatan. Berdasarkan hasil observasi pemberian posisi yang paling sering dilakukan pada 6 bayi ini yaitu posisi supinasi dan pronasi. Berdasarkan hasil studi pendahuluan tersebut maka peneliti tertarik untuk melakukan penelitian tentang pemberian posisi pada bayi prematur terhadap pengosongan lambung diruang Perinatologi RSUPN Dr. Cipto Mangunkusumo. Penelitian ini dilakukan untuk melihat perbedaan efektifitas miring kanan, miring kiri dan pronasi terhadap kejadian muntah dan adanya residu pada lambung.

\section{METODE}

Penelitian ini dilakukan pada bulan April 2017. Jenis penelitian ini merupakan penelitian kuantitatif dengan menggunakan desain quasi experiment dengan rancangan pre dan post without control group design. Jumlah sampel yang diambil yaitu 20 bayi premature yang terpasang orogastric tube (OGT) yang dirawat di ruang perinatologi RSUPN Dr. Cipto Mangunkusumo dengan teknik pengambilan sampel yang digunakanadalah dengan consecutive sampling method dengan kriteria sampel bayi prematur dalam kondisi stabil dengan usia gestasi kurang dari 36 minggu yang menggunakan OGT tanpa penyakit penyerta seperti NEC, pneumotoraks, atelektasis paru dan kembar siam.

Sebelum dilakukan penelitian, peneliti sudah meminta ijin dan menjelaskan prosedur penelitian kepada orang tua bayi melalui informed consent yang kemudian ditandatangani oleh orang tua bayi. Selain itu, peneliti juga sudah meminta ijin untuk melakukan penelitian kepada kepala ruang perawatan neonatus, serta dokter dan perawat yang merawat bayi yang akan dilakukan penelitian.

Pemberian posisi dilakukan oleh peneliti didampingi oleh perawat yang ada di ruang perawatan bayi. Posisi yang diberikan pada setiap bayi sama yaitu posisi miring kanan, pronasi dan miring kiri. Intervensi yang dilakukan pada hari pertama adalah pemberian posisi miring kanan, hari kedua pemberian posisi pronasi dan hari ketiga pemberian posisi miring kiri pada bayi prematur. Masing-masing pemberian posisi dilakukan selama 3 jam. Sebelum dilakukan pemberian posisi bayi diberikan minum terlebih dahulu sesuai dengan jenis dan jumlah nutrisi yang telah ditentukan.

Pengukuran residu lambung dan observasi muntah dilakukan selesai dilakukan pemberian posisi pada bayi, yaitu 3 jam setelah pemberian nutrisi. Residu lambung dilihat dengan cara mengambil residu lambung dengan spuit setelah pemberian posisi atau 3 jam setelah bayi diberikan nutrisi. Hasil pengukuran dicatat dalam lembar observasi yang berisi hasil pengukuran yang terdiri dari jumlah pemberian nutrisi, jenis nutrisi, penggunaan oksigen, kejadian muntah dan jumlah residu lambung pada masing-masing intervensi. Analisis data residu lambung menggunakan Uji Wilcoxon. 


\section{HASIL}

Hasil gambaran karakteristik responden pada bayi prematur yaitu sebagai berikut:

Tabel 1. Karakteristik pada Bayi Prematur

\begin{tabular}{lcc}
\hline \multicolumn{1}{c}{ Variabel } & Mean & SD \\
\hline Usia gestasi & 31,05 & 2,91 \\
Usia kronologis & 19,40 & 17,13 \\
Berat badan lahir & 1450 & 393,23 \\
Berat badan sekarang & 1622 & 312,6 \\
\hline
\end{tabular}

Berdasarkan analisis tabel 1, didapatkan bahwa rata-rata usia gestasi bayi prematur yang menjadi responden yaitu 31,05 minggu dengan rata-rata usia kronologis sebesar 19,4 hari. Rata-rata berat badan saat dilakukan penelitian yaitu 1622 gram dengan berat badan lahir 1450 gram.

Gambaran karakteristik responden pada masing-masing intervensi yaitu sebagai berikut:

Tabel 2 Karakteristik Responden pada Masing-Masing Intervensi

\begin{tabular}{llccc}
\hline \multirow{2}{*}{\begin{tabular}{l} 
Variabel \\
\cline { 3 - 4 }
\end{tabular}} & Hasil ukur & Miring kanan & Pronasi & Miring kiri \\
\cline { 3 - 5 } & & $\mathrm{n}(\%)$ dan mean (SD) & $\begin{array}{c}\mathrm{n}(\%) \text { dan } \\
\text { mean }(\mathrm{SD})\end{array}$ & $\begin{array}{c}\mathrm{n}(\%) \text { dan } \\
\text { mean }(\mathrm{SD})\end{array}$ \\
\hline Jumlah pemberian nutrisi & & $20,20 \mathrm{ml}(10,11)$ & $\begin{array}{c}20,55 \mathrm{ml} \\
(10,48)\end{array}$ & $\begin{array}{c}20,85 \mathrm{ml} \\
(10,53)\end{array}$ \\
\hline Jenis nutrisi & ASI & $11(55 \%)$ & $9(45 \%)$ & $9(45 \%)$ \\
\cline { 2 - 5 } & Susu formula & $9(45 \%)$ & $11(55 \%)$ & $11(55 \%)$ \\
\hline Muntah & Tidak & $13(65 \%)$ & $19(95 \%)$ & $17(85 \%)$ \\
\cline { 2 - 5 } & Ada & $7(35 \%)$ & $1(5 \%)$ & $3(15 \%)$ \\
\hline Residu lambung & & $0,36(0,47)$ & $0,48(0,64)$ & $0,66(0,69)$ \\
\hline
\end{tabular}

Berdasarkan tabel 2. dapat disimpulkan bahwa rata-rata jumlah pemberian nutrisi pada masing-masing intervensi sama yaitu rata-rata $20 \mathrm{ml}$ dengan jenis pemberian ASI paling banyak pada posisi miring kanan. Bayi prematur paling banyak tidak mengalami muntah pada posisi pronasi yaitu sebesar $95 \%$ dengan nilai p 0,001.
Residu lambung yang diukur pada bayi prematur paling sedikit pada posisi miring kanan yaitu sebesar $0,36 \mathrm{cc}$.

Gambaran perbedaan residu lambung pada pemberian posisi miring kanan, pronasi dan miring kiri dapat disajikan sebagai berikut :

Tabel 3. Uji Analisis Bivariat

pada Masing-masing Intervensi Pemberian Posisi

\begin{tabular}{ccccc}
\hline Variabel & Intervensi & $\begin{array}{c}\text { Intervensi } \\
\text { pembanding }\end{array}$ & Selisih rerata & Nilai p \\
\hline Residu lambung & Pronasi & Miring kanan & 0,125 & 1,0 \\
\cline { 2 - 4 } & Miring kanan & Miring kiri & 0,285 & 0,122 \\
\cline { 2 - 4 } & Miring kiri & 0,37 & $0,017^{*}$ \\
\hline
\end{tabular}

*signifikan pada $\alpha<0,05$ 
Hasil penelitian dapat dilihat bahwa selisih rerata pada posisi pronasi dibandingkan dengan miring kanan 0,125 dengan nilai $\mathrm{p}$ 1,0 , sedangkan selisih rerata posisi pronasi dibandingkan dengan miring kiri 0,285 dengan nilai $\mathrm{p}$ 0,122. Selisih rerata miring kanan dibandingkan dengan miring kiri 0,37 dengan nilai $\mathrm{p}$ 0,017 sehingga dapat disimpulkan bahwa posisi miring kanan lebih signifikan mengurangi residu lambung dibandingkan dengan posisi miring kiri.

\section{PEMBAHASAN}

Berdasarkan analisis tabel 1, didapatkan bahwa rata-rata usia gestasi bayi prematur yang menjadi responden yaitu 31,05 minggu. Sistem gastrointestinal pada bayi prematur akan berkembang secara lengkap pada usia gestasi 20 minggu. Imaturitas pada sistem gastrointestinal meliputi imaturitas fungsi motilitas, enzim digesti, respon hormonal, kolonisasi bakteri dan imunitas pada bayi. Bayi prematur juga akan mengalami imaturitas fungsi mekanik pada sistem gastrointestinal. Imaturitas fungsi mekanik ini meliputi koordinasi menghisap dan menelan, kemampuan sfingter gastroesofagus, pengosongan lambung dan motilitas usus. Bayi prematur yang lahir dengan usia gestasi kurang dari 34 minggu akan menunjukkan gejala gastrointestinal refluk, pengosongan lambung yang lambat, serta distensi abdomen. Hal ini dapat menyebabkan bayi prematur mengalami risiko terjadinya risiko infeksi pada system gastrointestinal (Fanaro, 2013). Pemberian posisi pada bayi diperlukan oleh bayi prematur untuk mengurangi resiko terjadinya infeksi sistem gastrointestinal.
Hasil analisis tabel 2 menunjukkan bahwa 19 bayi $(95 \%)$ tidak mengalami muntah pada saat dilakukan pemberian posisi pronasi dengan nilai p 0,001 (pvalue $<0,05$ ). Bayi yang tidak mengalami muntah pada posisi miring kiri sebesar 17 bayi dengan nilai p 0,002 (nilai $\mathrm{p}<0,05$ ), sedangkan bayi yang diposisikan miring kanan yang tidak mengalami muntah sebesar 13 bayi denga nilai p 0,18 (pvalue $>0,05$ ).

Hal ini menunjukkan bahwa pemberian posisi pronasi dan miring kiri pada bayi prematur berpengaruh secara signifikan terhadap kejadian muntah.Hasil penelitian ini sesuai dengan penelitian yang dilakukan oleh Ewer, James dan tobin (1999) yang menunjukkan bahwa pemberian posisi memiliki pengaruh yang signifikan terhadap kejadian muntah dengan nilai $\mathrm{p}<0,001$. Hasil penelitian ini juga menunjukkan bahwa kejadian muntah paling sedikit pada posisi pronasi, kemudian miring kiri dan miring kanan.

Kejadian muntah pada bayi prematur disebabkan karena lower esophageal sphinter (LES) belum matur. Bayi prematur akan mengalami relaksasi LES, sehingga terbentuk rongga antara lambung dan esofagus. Cairan dan gas dari lambung akan naik ke esofagus dan menutup saluran pernapasan, sehingga bayi akan mengalami muntah dan gangguan sistem pernapasan (Carter,2012). Kejadian muntah ini merupakan salah satu tanda dan gejala adanya gastroesophageal reflux (GER). Pengosongan lambung yang lama dan imaturitas pada pergerakan esophagus menyebabkan muntah dan terjadinya GER pada bayi prematur (Kultursay, 2012). 
Pemberian posisi pronasi dan lateral direkomendasikan untuk mencegah dan menangani bayi dengan GER (Efendi, Sari, Riyantini,..Lestari, 2019). Pemberian posisi pronasi dan miring kiri dianjurkan untuk mencegah refluks pada bayi prematur, anak dan dewasa. Kejadian refluks dan relaksasi lower esophageal sphincter (LES) lebih sering pada bayi yang diposisikan miring kanan dibandingkan dengan posisi miring kiri. Pemberian posisi pronasi atau miring kiri merupakan intervensi yang mudah dilakukan untuk penanganan GER dan mencegah periode apnea pada saat pemberian minum pada bayi prematur, karena pada posisi pronasi dan miring kiri akan mencegah terjadinya relaksasi pada LES sehingga tidak menutup saluran pernapasan dan tidak menyebabkan terjadinya refluks (Kultursay, 2012).

Hasil analisis pada tabel 2. menunjukkan jenis nutrisi yang diberikan pada posisi pronasi dan miring kiri lebih banyak menggunakan susu formula sebesar 11 bayi (55\%), sedangkan pada posisi miring kanan lebih banyak menggunakan ASI sebesar 11 bayi (55\%). Pemberian ASI, terutama kolostrum ibu pada minggu pertama kehidupan bayi akan berdampak pada kematangan sistem gastrointestinal dan dapat meningkatkan imunitas pada bayi. ASI mengandung air sebanyak $87.5 \%$, oleh karena itu bayi yang mendapat cukup ASI tidak perlu lagi mendapat tambahan air walaupun berada di tempat yang mempunyai suhu udara panas. Kekentalan ASI sesuai dengan saluran cerna bayi, sedangkan susu formula lebih kental dibandingkan ASI, sehingga ASI lebih mudah diserap oleh sistem pencernaan pada bayi. (Perella, Hepworth, Simmer, \& Geddes, 2015).
Penambahan lingkar perut dan distensi abdomen pada bayi prematur dipengaruhi oleh usia gestasi, jumlah pemberian minum, dan indikator pengosongan lambung. Ratarata usia gestasi bayi prematur pada proyek inovasi ini yaitu 31,05 minggu, sehingga hal ini menunjukkan usia gestasi pada bayi prematur kurang dari 34 minggu dan akan mengalami pengosongan lambung yang lambat sehingga akan menyebabkan risiko terjadinya distensi abdomen. Rata-rata bayi prematur juga sudah mendapatkan nutrisi secara penuh, sehingga dapat menyebabkan distensi abdomen pada bayi prematur.

Pengosongan lambung pada bayi prematur lebih lambat dibandingkan pada bayi yang matur, hal ini disebabkan karena imaturitas fungsi lower esophageal, dan pergerakan usus yang lambat. Pengosongan lambung pada bayi prematur juga berhubungan dengan pemberian minum secara dini atau tidak. Pemberian nutrisi secara dini akan membantu pematangan fungsi gastrointestinal dan mempercepat penyerapan lambung ( $\mathrm{Li}$, Lin, Torazza, Parker, Talaga, \& Neu, 2014).

Distensi abdomen pada bayi prematur juga dapat disebabkan oleh gangguan pada perjalanan mekonium dan penurunan bising usus. Peningkatan lingkar perut lebih dari 2 $\mathrm{cm}$ berhubungan dengan terjadinya intoleransi pemberian minum (Carter, 2012). Pengaturan posisi pronasi dapat menurunkan kejadian intoleransi pemberian minum enteral karena pada posisi pronasi akan terjadi peningkatan pertukaran gas dengan menurunkan tekanan pleura dan meningkatkan area ventilasi yang berada dekat dengan rongga diafragma, sehingga dapat menurunkan distensi abdomen. Pemberian posisi pronasi juga akan menurunkan retensi pertukaran gas di 
saluran gastrointestinal dan meningkatkan motilitas saluran gastrointestinal (Sangers et. al, 2013).

Pemberian posisi miring kanan setelah pemberian minum juga dapat mempercepat penyerapan lambung dan mencegah terjadinya distensi abdomen. Penelitian yang dilakukan oleh Van Wijk (2007) menunjukkan bahwa pengosongan lambung lebih cepat pada pemberian posisi miring kanan setelah pemberian minum dibandingkan pada pemberian posisi miring kiri dengan nilai p 0,0006 (nilai p<0,005).

Hasil analisis tabel 3 menunjukkan perbandingan perbedaan residu lambung pada masing-masing intervensi. Tidak ada perbedaan yang bermakna antara pemberian posisi miring kanan dibandingkan dengan posisi pronasi maupun posisi miring kiri dibandingkan dengan pronasi, tetapi ada perbedaan yang bermakna pada pemberian posisi miring kanan dibandingkan dengan posisi miring kiri. Hal ini juga menunjukkan bahwa posisi miring kanan dan pronasi lebih efektif untuk mengurangi residu lambung dibandingkan dengan posisi miring kiri.

Bayi yang diberikan posisi miring kanan letak lambungnya ada di posisi atas abdomen dan tidak terdesak oleh organ yang lain, sehingga pengosongan lambung lebih cepat karena tidak ada tekanan pada lambung. Hasil penerapan evidence based nursing practice ini sesuai dengan penelitian Sangers (2013) yang membandingkan antara empat posisi yaitu pronasi, supinasi, miring kanan dan miring kiri pada 2 kelompok bayi. Hasil penelitian ini menunjukkan bahwa ada perbedaan yang signifikan antara kelompok yang diberikan posisi miring kiri dibandingkan dengan kelompok yang diberikan miring kanan (nilai $\mathrm{p}<0,001)$ atau pronasi $(0,049)$.

Penelitian yang sama juga dilakukan oleh Husein (2012) yang membandingkan antara posisi lateral kanan dan semi recumbent terhadap residu lambung pada bayi dibawah usia 1 tahun. Penelitian ini dilakukan pada 35 bayi yang diberikan posisi lateral kanan atau semi recumbent setelah 10-15 menit dan aspirasi lambung dilakukan sebelum pemberian minum berikutnya. Hasil penelitian ini menunjukkan ada hubungan antara pemberian posisi miring kanan dan semirecumbent terhadap pengeluaran residu lambung (nilai $\mathrm{p}<0,5$ ).

Pengaturan posisi pronasi dilakukan dengan menelungkupkan bayi dimana ekstremitas bagian bawah fleksi dan kepala dimiringkan ke salah satu sisi,tulang panggul diganjal bantal kecil dan gulungan kain diletakkan di bawah dada supaya abdomen tidak tertekan. Posisi ini dapat mempercepat pengosongan lambung sehingga lebih baik mentoleransi minum, meningkatkan ventilasi dan oksigenasi. Penelitian yang dilakukan oleh Elser (2012) bertujuan untuk mengidentifikasi posisi yang paling tepat setelah pemberian minum enteral untuk menurunkan kejadian intoleransi pemberian minum. Penelitian ini dilakukan pada bayi usia 0 hari sampai 2 bulan yang memperoleh pemberian minum enteral. Hasil penelitian ini menunjukkan bahwa posisi pronasi lebih efektif untuk menurunkan residu lambung dan mengatasi masalah GER. Hasil penerapan evidence based nursing ini juga menunjukkan bahwa bayi yang diberikan posisi pronasi $95 \%$ tidak mengalami muntah, dibandingkan dengan posisi miring kanan dan miring kiri, 
sehingga dapat mencegah terjadinya GER, yang dapat menyebabkan apnea, aspirasi pneumonia dan penyakit paru-paru kronis.

\section{KESIMPULAN}

Posisi yang paling efektif untuk mengatasi masalah pengosongan lambung adalah posisi pronasi jika dilihat dari kejadian muntah, sedangkan jika dilihat dari pengeluraran residu lambung posisi miring kanan lebih efektif menurunkan residu lambung. Hasil penelitian ini dapat dijadikan acuan pemberian posisi pada bayi prematur dengan distensi abdomen, dan penyerapan lambung yang lambat lebih baik diposisikan miring kanan atau pronasi minimal 1 jam setelah pemberian minum, sedangkan bayi prematur dengan GER atau GERD lebih baik diberikan posisi miring kiri atau pronasi pada saat pemberian minum untuk mencegah terjadinya refluks atau muntah.

\section{DAFTAR PUSTAKA}

Abdelmaaboud, M., Eissa, A., Eldakrouri, A.F., \& Mohammed, A. (2015). Incidence of feeding intelorance and necrotizing enter colitis in preterm growth restricted neonates with abnormal antenatal doppler studies. Journal of Food \& Nutritional Disorder, 4(1), 1-6. http://dx.doi.org/10.4172/23249323.1000165

Carter, B.M. (2012). Feeding intolerance in preterm infants and standard of care guidelines for nursing assessments. Newborn \& Infant Nursing Reviews, 12(4), 187-201.

Elser, H.E. (2012). Positioning after feedings: What is the evidence to reduce feeding intolerances? Advances in Neonatal Care, 12 (3), 172-175.

Efendi, D., Sari, D., Riyantini, Y., Novardian., Anggur, D., \& Lestari, P. (2019). Pemberian Posisi (Positioning) Dan Nesting Pada BayiPrematur: Evaluasi Implementasi Perawatan Di NeonatalIntensive Care Unit (NICU). Jurnal Keperawatan Indonesia. 22 (3), 169-181. DOI: 10.7454/jki.v22i3.619

Fanaro, S. (2013). Feeding intolerance in the preterm infant. Early Human Development, 89, 513-520.

Hwang, S.K., Ju, H.O., Kim, Y.S., Lee, H.Z. (2003). Effect of body position and time after feeding on gastric residuals in LBW infants. Journal of Korean Academy of Nursing, 3 (4), 487-494.

Hockenberry, E.M., Wilson, D., Winkelstein, M. L., \& Schwartz, P. (2013). Wong's essential of pediatric nursing ( $8^{\text {th }}$ edition). $\mathrm{St}$ Louis: Mosby, Inc.

Hussein, H.A. (2012). The difference between right side and semi recumbent positions after feeding on gastric residual volume among infants. Journal of American Science, 8 (1), 127-132.

Kultursay, N. (2012). Gastroesophageal reflux (GER) in preterms: current dilemmas and unresolved problems in diagnosis and treatment. The TurkishJournal of Pediatrica, 54, 561-569.

Li, Y.F., Lin, H.C., Torazza, R.M., Parker, L., Talaga, E., \& Neu.J. (2014). Gastric residual evaluation in 
preterm neonates: A useful monitoring technique or hidrance? Pediatrics and Neonatology, 55, 335-340

Potts, N.L., \& Mandelco, B.L. (2012). Pediatric nursing: Caring for children and their famillies. $\left(3^{\text {rd }}\right.$ edition). USA: Delmar.

Sangers, H., Jong, P.M.,Mulder, S.E., Stigter, G.D., Berg, C.M., Pas, A.B., \& Walther, F.J. (2013). Outcomes of gastric residuals whilst feeding preterm infants in various body positions. Journal of Neonatal Nursing, $\quad 19, \quad 337-341$. http://dx.doi.org/10.1016/j.jnn.2012 .12 .003

Van wijk, M.P., Benninga, M.A., Dent, J., Lontis, R., Goodchild, L., McCall, L.M.,.....\& Omari, t. (2007). Effect of body position changes on postprandial gastroesophageal reflux and gastric emptying in the health premature neonate. The Journal of Pediatrics, 151(6), 585590 


\section{HALAMAN INI SENGAJA DI KOSONGKAN}

